\title{
Tourism Attractions and Infrastructures Evaluation in Loksado Tourism Area, Hulu Sungai Selatan Regency, South Kalimantan
}

\author{
Yulian Firmana Arifin*
}

Study Program of Civil Engineering, Faculty of Engineering, Lambung Mangkurat University, Banjarbaru, Indonesia

\begin{abstract}
The aim of the study is to descriptively evaluate the tourism attraction and infrastructure in Loksado, Hulu Sungai Selatan Regency, South Kalimantan. Field data was collected through ground checking and listing all aspects of infrastructures, including the condition of road, transportation, accommodation, bridge, houses, and conditions of the tourism object. The result shows that tourism grows significantly in Hulu Sungai Selatan Regency, with Loksado area as a hot spot for tourism activities and developments. Loksado is productive in term of natural and cultural resources that are potential to be developed as the tourist attraction. However, there are problems related to the accessibility with main threat from slippery clay path and landslide. Many build facilities and infrastructures seem to be less managed, and many of them are in development phases. These lead to the weaknesses of the tourism development in Loksado. Community-based tourism appears to be important to promote, with the particular objectives is increasing the local benefit to increase community participation in tourism attraction and infrastructure management. It is also possible to increase local community in accommodation services.
\end{abstract}

Keywords: infrastructure, landslide, Loksado, tourism facility, tropical forest.

\section{INTRODUCTION}

Nowadays, tourism is an important business in many areas. Tourism facility is an essential component in the travel destinations. It has contribution and relationship to create travel satisfaction, and therefore influence the sustainability of tourism destination. Developing tourism and hospitality properties and facilities become ultimate program for planner and local government. It is especially important as a crucial factor for human relaxation and satisfaction.

The tourism industry is moving through a best quality standard service in all aspect of tourism facility and infrastructure [1]. The close relationship between infrastructure and tourism development has been theoretically and practically confirmed by many researchers $[2,3,4]$. Many countries are in early stages of development, but there is a trend to the rapid and massive development. The development of tourism infrastructure, therefore, should consider environmental aspect, in which biodiversity is important. In tropical countries such as Indonesia, such issues are of particular importance $[5,6]$.

Tourists who are visited many interesting objects in tourism industry need fundamental

\footnotetext{
* Correspondence address:

Yulian Firmana Arifin

Email : yulianfirmana@yahoo.com

Address : Faculty of Engineering, University of Lambung Mangkurat, Banjarbaru, Indonesia
}

aspect, which is important to enhance visitor's satisfaction. It can be classified into accessibility, amenity, attraction, and ancillary services. The requirement of such issue was considered necessary and determines the success of tourism destinations. The accessibility provides access to the tourist attraction and facilitates tourist movement to explore all of the desired attraction and destinations [7].

Modern countries often supported by the high quality of tourism facility. The problem of the infrastructure often found in developing countries. The most common problem, especially in an infrastructure quality, is a lack of human resources capacity in the planning phase. This relatively complex phenomena produces a large number of operational barrier and limitation. Tourism infrastructure and the facility was developed and focused on the physical and aesthetical aspect and loss the consideration of the environmental issue. The involvement of local community in tourism infrastructure management was inadequate. This becomes the limitation for sustainable infrastructure management in many developing countries $[5,6,8]$.

Hulu Sungai Selatan (HSS) Regency has many tourist destinations including cultural, historical, natural, religious, culinary, and art tourisms [9]. One of the most famous nature-based destinations is Loksado. In 2011, Loksado has been declared as national tourism strategic area 
(Kawasan Strategis Pariwisata Nasional) [10]. It includes sub-regencies of Kandangan, Angkinang, Telaga Langsat, Padang Batung, and Loksado. The declaration of such area as a strategic area of tourism destination in national levels related to the natural and cultural richness of Loksado area.

The area of Loksado is various in term of landscapes feature, ranging from tropical forest, slopes, and rivers. The area is home to local people called Dayak Meratus. The local people have the indigenous knowledge and local wisdom that contribute significantly to resources utilization. The development of tourism in Hulu Sungai Selatan needs the comprehensive planning which are able to ensure the sustainability and competitiveness of Hulu Sungai Selatan as a travel destination. The development of tourism infrastructure and facility, as well as amenity facility, is crucial factors that should be developed in Hulu Sungai Selatan. The aim of the study is to descriptively evaluate on the tourism attraction and infrastructure in Hulu Sungai Selatan Regency, South Kalimantan to support the tourism industry.

\section{RESEARCH METHOD}

\section{Study Area}

The research was conducted at Hulu Sungai Selatan (HSS) Regency in South Kalimantan. Geographically, HSS is a hilly area with many hills exists to construct the landscape. There are many slopes and rivers stream in HSS. The average of temperature was about $26.25^{\circ} \mathrm{C}-$ $27.25^{\circ} \mathrm{C}$ and humidity was about $76.5 \%-77 \%$. Hulu Sungai Selatan Regency consists of several sub-regency, namely Daha Utara, Daha Barat, Daha Selatan, Kalumpang, Simpur, Kandangan, Angkinang, Telaga Langsat, Sungai Raya, Padang Batung and Loksado (Fig. 1). Loksado has been known as a tourism destination in HSS. The Loksado occupy an area about $33.89 \mathrm{~km}^{2}$. Loksado Sub-regency has 11 villages with Dayak Loksado as a dominant local population. Some area located at $1000 \mathrm{~m}$ asl, with averages of slope about $25 \%$ to $40 \%$. These lead to the soil erosion in Loksado area. The incident of landslide often occurs in the area with steep area and loss of vegetation, such as Tanuhi village. Agricultural commodity community plantation includes rubber, clove, and peer [11].

\section{Method}

Methods consist of several steps, namely preparation, identification, analysis, and conclusion. Field data was collected through ground checking and listing all aspect of infrastructure, including the condition of road, transportation, accommodation, bridge, houses, and conditions of tourism object. Secondary data was collected from tourism office and Regency Planning Office (BAPPEDA) in Kandangan. Interviews with tourists and the officers was performed in Kandangan. Data was analyzed descriptively.

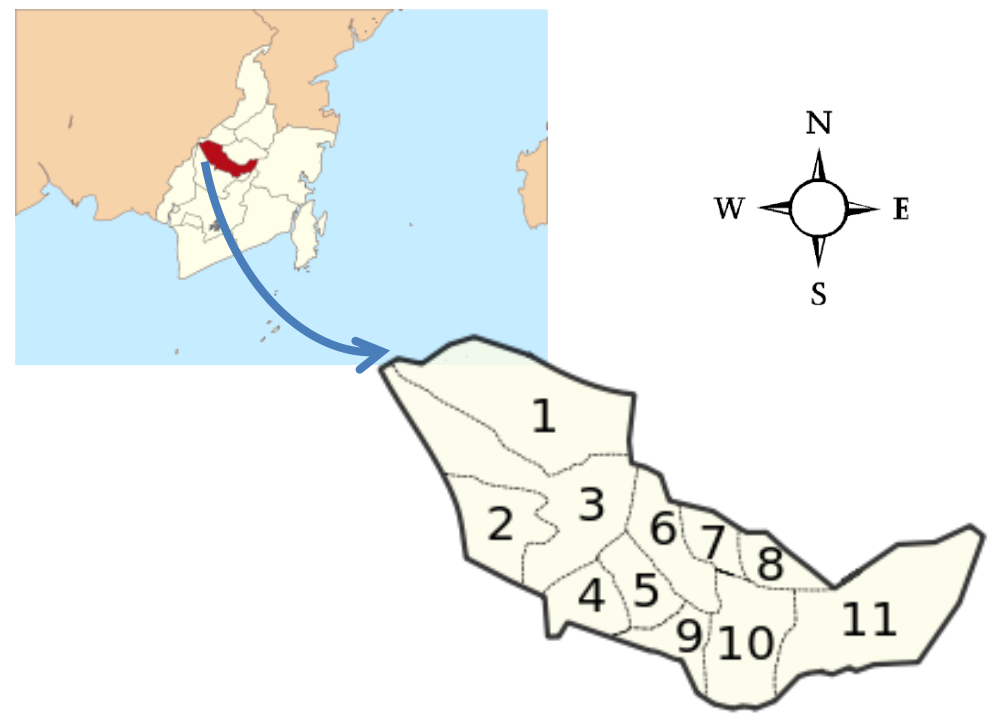

Figure 1. Map of Hulu Sungai. Source: Regency Planning Office (BAPPEDA) of Hulu Sungai Selatan Regency Notes: (1) Daha Utara, (2) Daha Barat, (3) Daha Selatan, (4) Kalumpang, (5) Simpur, (6) Kandangan, (7) Angkinang, (8) Telaga Langsat, (9) Sungai Raya, (10) Padang Batung and (11) Loksado 
Tourism Attractions and Infrastructures evaluation in Loksado Tourism Area,

South Kalimantan (Arifin)

\section{RESULT AND DISCUSSION \\ Accessibility}

Access is essential for tourism [12]. Most people (especially local tourists) have insufficient time for their travel, and if the tourism attractions are hard or take a long time to reach, few tourists are likely to visit. The aspect related to the accessibility includes roads, trails, and bridges. In Loksado area, a threat to the accessibility is landslide which area often occurs in the rainy season. The incident of landslides mainly related to the forest and land disturbance. Absences of vegetation lead to the weak soil structure, which led to the erosion and landslide. According to statistical data, annual rainfall can reach $1,819.5 \mathrm{~mm}$ with the number of rain days about 181 days. The high rate of rainfall seems to contribute to the incident of landslide and erosion. Hazard intensity appears to arise in the rainy season when the number of rainfall was high [11].

A typical retaining wall used to overcome and prevent the landslide in Loksado is a wall of gabion (Fig. 2). The gabion is a wire-mesh container filled with stones and used in modular fashion to fortify slope and reduce erosion [13].

Besides the aesthetical and natural look, this method is selected because stone is widely available around the site. Figure 3 a shows an example of a slope failure occurred on the road between Tanuhi and Loksado in 2009. A retaining wall made of gabion was constructed in the current year to prevent further landslide (Fig. 3b).

A large slope failure happened and covered the whole construction in 2012 (Fig. 3c). Therefore, besides a retaining wall such as gabion, improving the condition of the plants on the slopes should be also performed. The use of vegetation for preventing and controlling slope failure and erosion has being practiced throughout the world [14].

Besides roads and slopes, the trails are also available in Loksado area. These connect Loksado with other attraction locations like Haratai waterfall. Figure 4 shows several trails with different conditions. There are clay pathway without any cover material (Fig. 4a), path covered by coarse grain such as gravel (Fig. 4b), and the other covered by concrete (Fig. 4c). The surface without a cover material is slippery, and it makes a problem for travelers to across the road.

The other infrastructure that is of concern in Loksado is bridges especially in the trails. The suspension bridges are accessible with different conditions as shown in Figure 5 . These bridges can only be crossed by people, bicycles, motorcycles, and other light transportations.

Water-transporting still contributes to the transportation system in many areas in HSS, including Loksado [15]. Water transportation in Loksado was facilitated by traditional bamboo boat/bamboo rafting. Traditionally, this vehicle was used to distribute crops and other agricultural product of local people in Loksado area. For a long time, river is one of the primary transportation tools in Loksado and it has been the part of local culture in Loksado. Recently, however, with the increase of the role of land transportation, the role of water transportation decreases. The bamboo rafting is used more for tourism than a medium of transportation (Fig. 6). The new road has been established, and many bridges were constructed to facilitate people movement in the terrestrial area. In other sides, it becomes opportunities for tourism development.
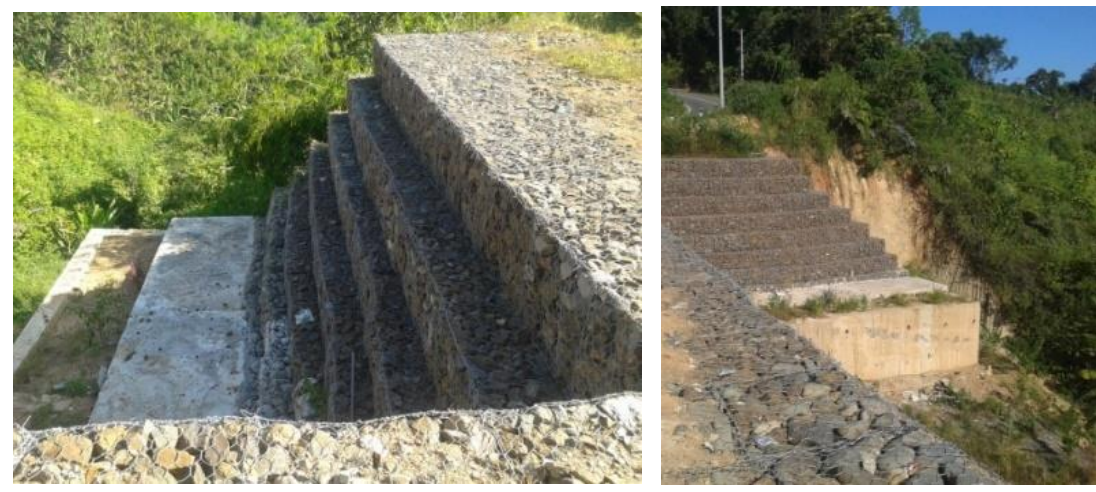

Figure 2. Gabion constructions in Loksado (personal documentation, 2017) 

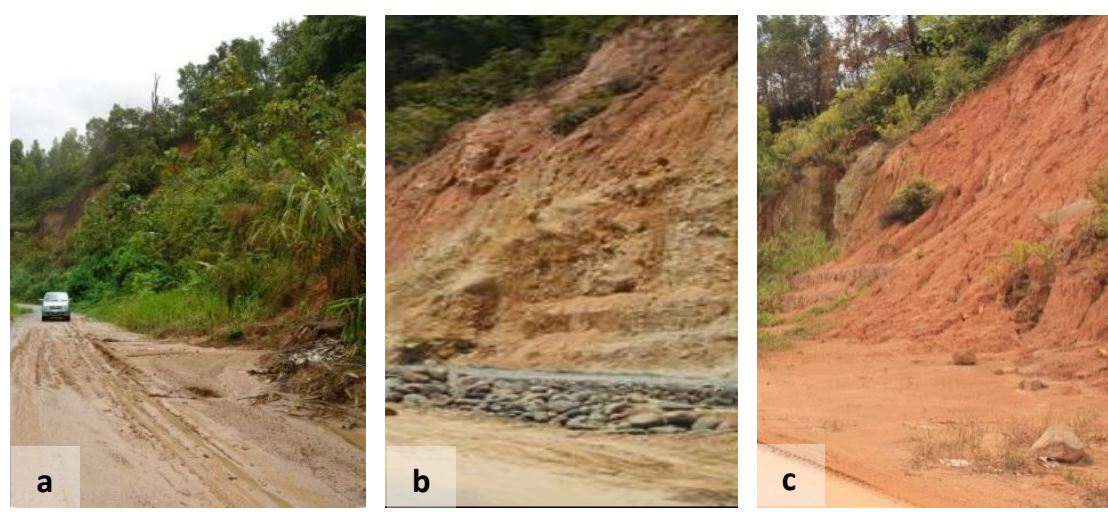

Figure 3. Landslides in Loksado Tourism Area (personal documentation, 2017)
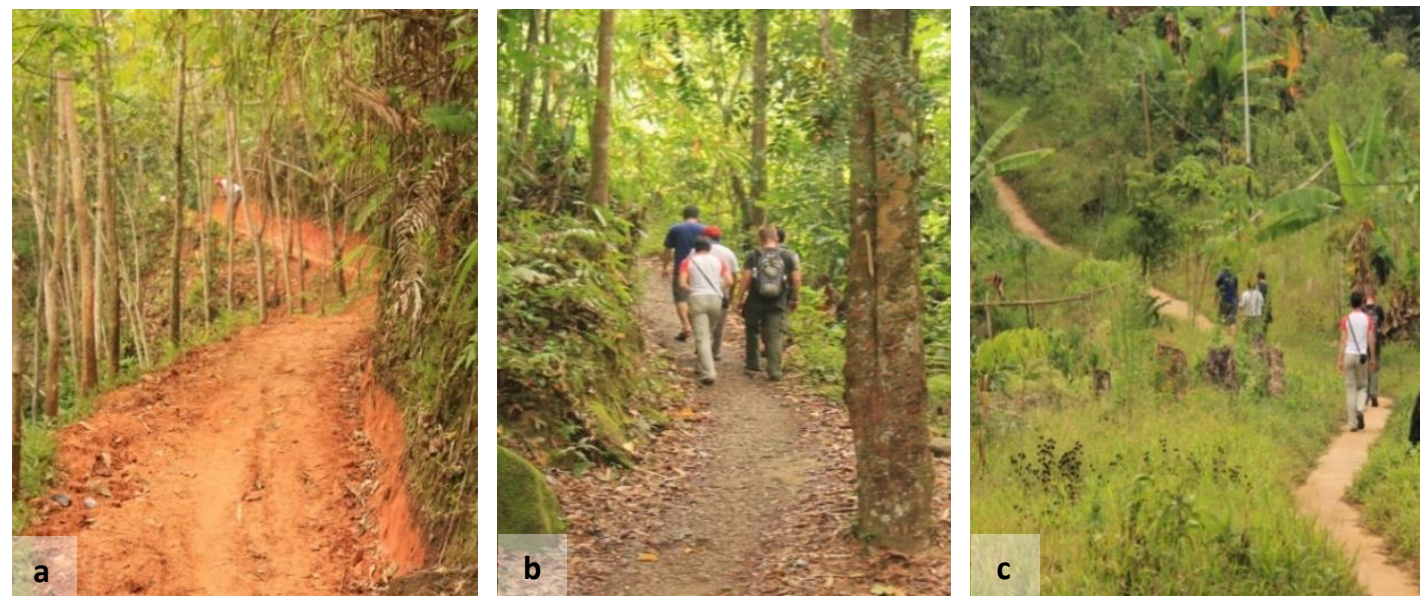

Figure 4. The Trails Connecting Loksado with Haratai Waterfall (personal documentation, 2017)
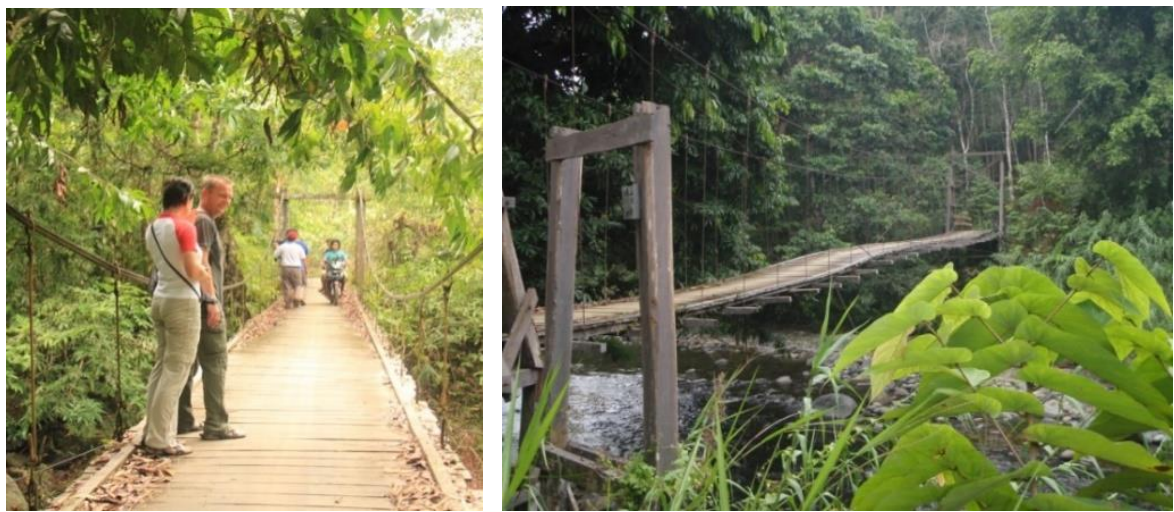

Figure. 5. The Suspension Bridge in Loksado Area (personal documentation, 2017)
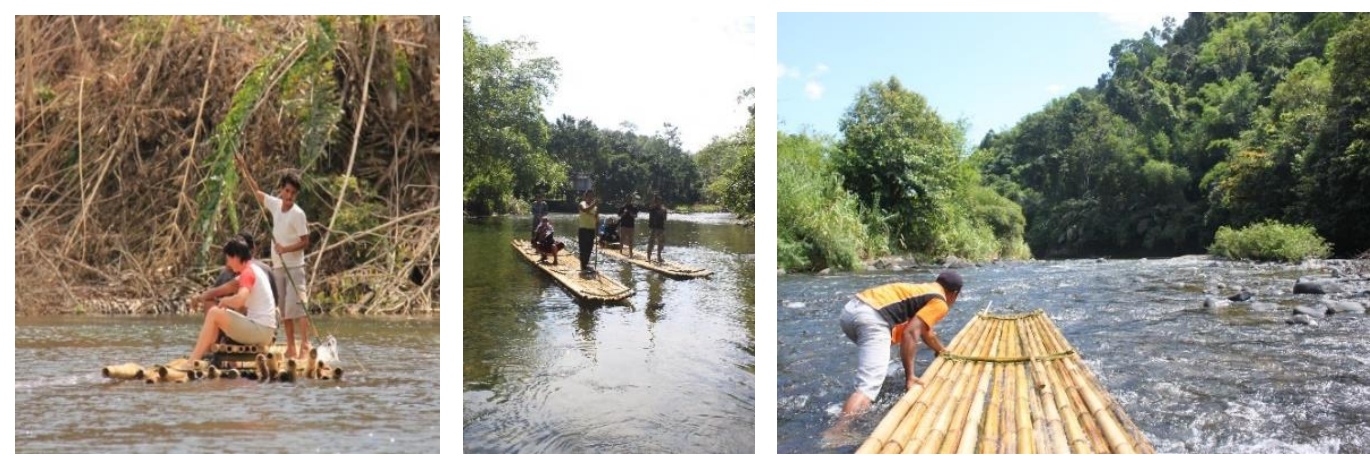

Figure 6. Bamboo rafting in Loksado (personal documentation, 2017) 
Tourism Attractions and Infrastructures evaluation in Loksado Tourism Area,

South Kalimantan (Arifin)

\section{Accommodation}

Accommodation is an important instrument in a tourism industry [1]. The accommodation was rare to found in Loksado, indicates that this sector should be improved significantly. There are no star hotel and or accredited hotel. All of the hotel and accommodation was simple to provide room for a stay in regular services as shown in Table 1.

The data from Table 1 shows that accommodation is limited. The number of room was limited, and in the future, it potentially becomes problems for tourism growth. The government should encourage privates sector to invest and join in tourism development sector.

Table 1. Hotel and accommodation in Hulu Sungai Selatan

\begin{tabular}{llc}
\hline Hotels & Location & rooms \\
\hline 1. Hot-water Spring Tanuhi & Tanuhi, Loksado & 20 \\
2. Wisma Loksado & Loksado & 8 \\
3. Graha Amandit & Loksado & 16 \\
4. Bangkau & Kandangan & 13 \\
5. Loksado & Kandangan & 10 \\
6. Mutia & Kandangan & 11 \\
7. Wisma Duta & Kandangan & 17 \\
8. Mahligai Antaludin & Kandangan & 8 \\
\hline
\end{tabular}

Source: Hulu Sungai Selatan Department of Tourism [16]

There are also opportunities to support community-based accommodation. Local government can strengthen and enhance the participation of local community in accommodation through cooperation concept. It is become the entry point to the establishment of community-based tourism, in which community received economic benefits from tourism sector $[17,18]$.

Problems seem to be related to the less understanding about tourism among the local community. Local government, academician, local NGOs and other tourism stakeholder has the responsibility to educate local people to be aware and understand about the potentiality of tourism.

\section{Attraction}

Loksado has both natural and human-made attraction. The original attraction object are a various form of biodiversity of landscape in Hulu Sungai Selatan Regency which also famous and rich with cultural attraction, including event, festival, and heritages. There are 11 calendar events of tourism; represent the commitment of HSS Regency to provides continuous event attraction to both international and domestic tourists. Loksado is famous for bamboo rafting which unique to the area. There are 9 natural attractions has been identified, including waterfall, hot spring, cave, and forest.

Human-made includes many objects which area developed by the government. It includes open area and park that provide spaces for the city dweller to enjoy nature. Many facilities in public space potentially attract tourist, but there is few management led to the many facilities in minor condition.

Many tourism facilities are under less management. Lack of funding and personal skill to manage of tourism attraction and facility seems to be the contributors for poor management of attraction and facility (Figu.7-8). Some attractions have potentials, form of tourism to be offered, tourist demands, and specific problems and many of them have similar cases (Table 2). According Table 2, attractions in Loksado have similar forms of tourism (i.e., natural tourism) and potentials of natural tropical forest views. From the analysis, several weaknesses were found in Loksado tourism area. It includes:

- Poor management of tourism facilities

- Quality of tourism corridor movement

- Attraction management

- Transportation, including road, sign board, and accessibility.

- Telecommunications network including internet

Poor management of tourism facilities includes the absence of an efficient maintenance management system. It is also one of the main concerns in maintaining public tourism infrastructure. To assure that all maintenance activities can be entirely performed, the control mechanism must be integrated by a particular team [19]. The difficulty, generally in Indonesia, is that the infrastructures are maintained by different ministry.

The last weakness is contrary to the desire of tourists to get peace and comfort without disruption by the telecommunications. However, the visitors, especially local tourists, always want to upload all their activities during their vacation directly and immediately. Therefore, the Internet is a necessity. 


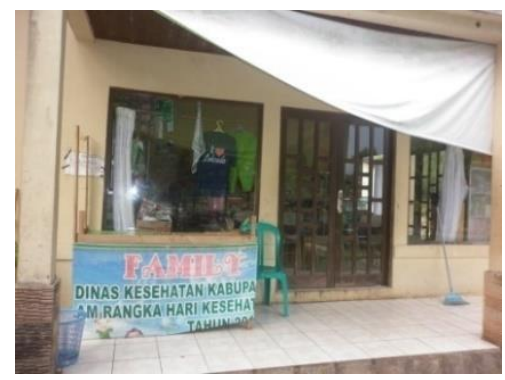

Cafeteria and souvenir shop

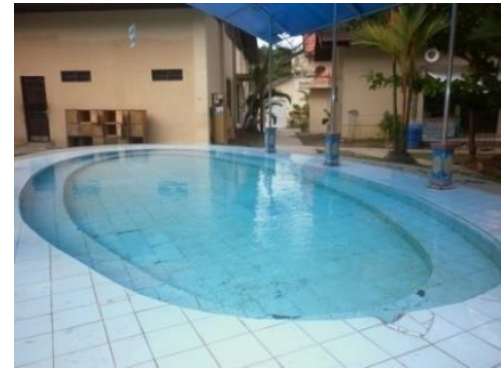

Hot spring

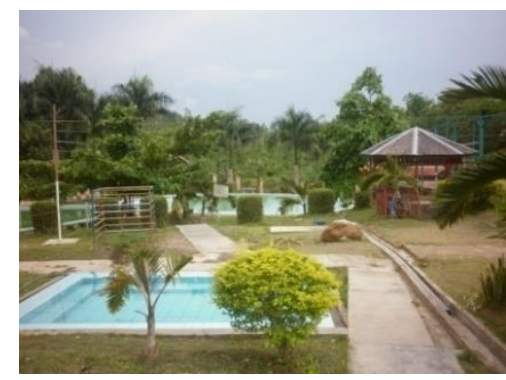

Human-made tourism object

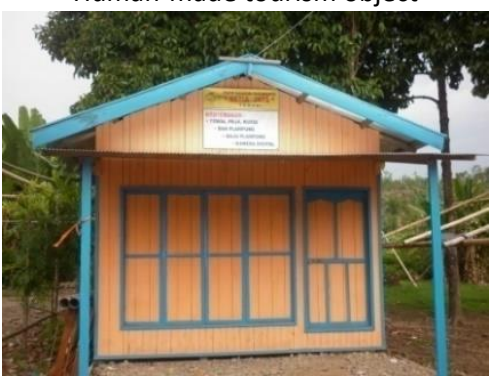

Rental booth

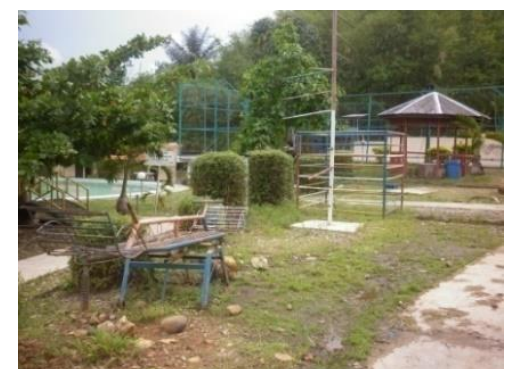

City park with less management

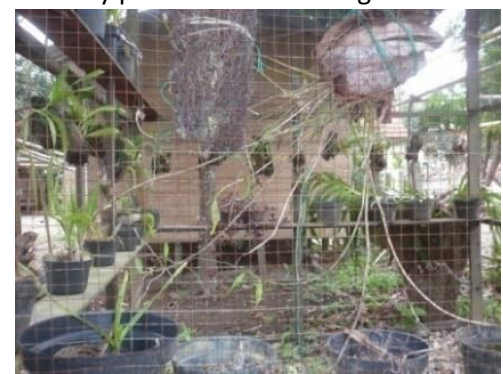

House of Orchids

Figure 7. Tourism attractions in Loksado Hulu Sungai Selatan

Sources: Regency Planning Office (BAPPEDA) of Hulu Sungai Selatan Regency

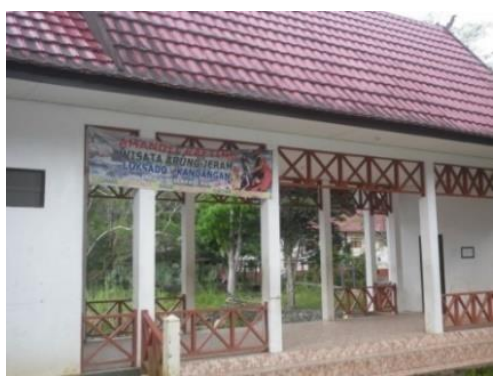

Bamboo rafting terminal

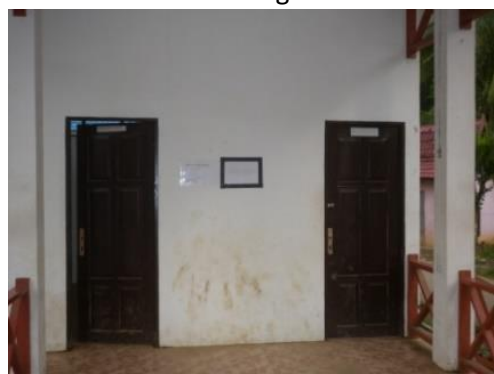

Toilet facilities
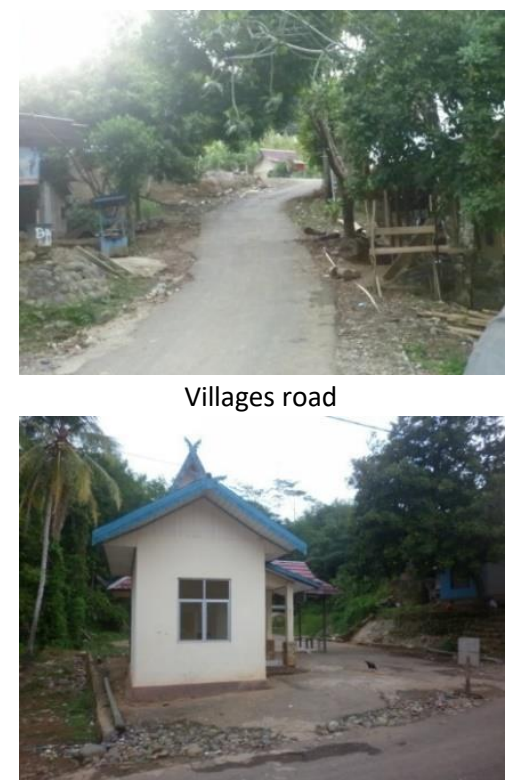

Information center

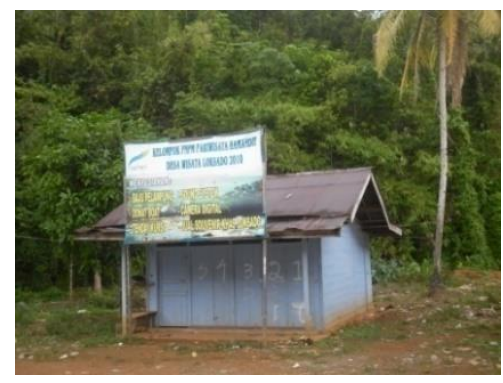

Souvenirs shop

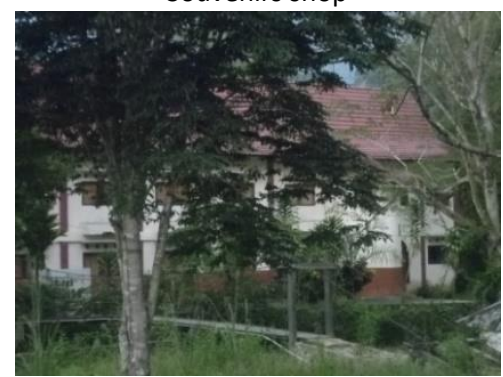

Accommodation

Figure 8. Tourism facilities in Loksado

Sources: Regency Planning Office (BAPPEDA) of Hulu Sungai Selatan Regency 
Tourism Attractions and Infrastructures evaluation in Loksado Tourism Area,

South Kalimantan (Arifin)

Table 2. Potentials, Forms, Tourist Demands, and Problems Facing by Tourism Attraction in Loksado

\begin{tabular}{|c|c|c|c|c|}
\hline $\begin{array}{l}\text { Natural Attraction } \\
\text { (Location) }\end{array}$ & Potentials & Problems & Forms of Tourism & Tourist Demand \\
\hline $\begin{array}{l}\text { Kantawan } \\
\text { Mountain } \\
\text { (Muara Hatip } \\
\text { Village, } 27 \text { km from } \\
\text { Kandangan) }\end{array}$ & $\begin{array}{l}\text { The views of natural } \\
\text { tropical forests with } \\
\text { diverse flora and } \\
\text { fauna typical of } \\
\text { Kalimantan }\end{array}$ & $\begin{array}{l}\text { Not well managed } \\
\text { Inadequate parking } \\
\text { areas }\end{array}$ & $\begin{array}{l}\text { Natural Tourism } \\
\text { Special interest tours } \\
\text { include: tracking, mountain } \\
\text { bike, rock climbing, hiking, } \\
\text { and bike trail }\end{array}$ & $\begin{array}{l}\text { public toilet, } \\
\text { restaurant, and } \\
\text { rest area }\end{array}$ \\
\hline $\begin{array}{l}\text { Tanuhi Hot Springs } \\
\text { (Tanuhi Village, } 33 \\
\text { km from } \\
\text { Kandangan) }\end{array}$ & $\begin{array}{l}\text { Thermal baths, pools } \\
\text { and cottages that } \\
\text { offer views of } \\
\text { unspoiled natural } \\
\text { atmosphere of } \\
\text { Loksado }\end{array}$ & $\begin{array}{l}\text { The cottages are not } \\
\text { well managed } \\
\text { Number of waiters } \\
\text { are limited } \\
\text { Lack of communi- } \\
\text { cations network }\end{array}$ & $\begin{array}{l}\text { Natural Tourism } \\
\text { Health travel and relaxation } \\
\text { with a hot water bath }\end{array}$ & $\begin{array}{l}\text { Improving of cottage } \\
\text { services } \\
\text { The availability of the } \\
\text { communications } \\
\text { network including } \\
\text { internet }\end{array}$ \\
\hline $\begin{array}{l}\text { Kilat Api Waterfall } \\
\text { (Tanuhi Village, } 34 \\
\text { km from } \\
\text { Kandangan) }\end{array}$ & $\begin{array}{l}\text { A one-level waterfall } \\
\text { with views of } \\
\text { unspoiled natural } \\
\text { atmosphere of } \\
\text { Loksado }\end{array}$ & $\begin{array}{l}\text { Unmanaged } \\
\text { Limited access due to } \\
\text { damage bridge } \\
\text { Lack of tourism } \\
\text { facilities }\end{array}$ & $\begin{array}{l}\text { Natural Tourism } \\
\text { Special interest tours } \\
\text { include: tracking, mountain } \\
\text { bike, rock climbing, hiking, } \\
\text { and bike trail }\end{array}$ & $\begin{array}{l}\text { public toilet, } \\
\text { restaurant, and } \\
\text { rest point, signboard, } \\
\text { telecommunications } \\
\text { network including } \\
\text { internet } \\
\end{array}$ \\
\hline $\begin{array}{l}\text { Tangkaramin } \\
\text { Waterfall (malinau } \\
\text { Village, } 36 \mathrm{~km} \text { from } \\
\text { Kandangan) }\end{array}$ & $\begin{array}{l}\text { A Three-level } \\
\text { waterfall with views } \\
\text { of natural tropical } \\
\text { forests with diverse } \\
\text { flora and fauna typical } \\
\text { of Kalimantan }\end{array}$ & $\begin{array}{l}\text { Not well managed } \\
\text { Lack of supporting } \\
\text { facilities }\end{array}$ & $\begin{array}{l}\text { Natural Tourism } \\
\text { Special interest tours } \\
\text { include: tracking, mountain } \\
\text { bike, rock climbing, hiking, } \\
\text { and bike trail }\end{array}$ & $\begin{array}{l}\text { public toilet, } \\
\text { restaurant, and } \\
\text { rest point, signboard, } \\
\text { telecommunications } \\
\text { network including } \\
\text { internet }\end{array}$ \\
\hline $\begin{array}{l}\text { Balai Adat } \\
\text { Bukit/Dayak (39 km } \\
\text { from Kandangan) }\end{array}$ & $\begin{array}{l}\text { The traditional house } \\
\text { of Dayak with its own } \\
\text { merits, culture is } \\
\text { extremely exist, } \\
\text { friendly community } \\
\end{array}$ & $\begin{array}{l}\text { Not well managed } \\
\text { Limited access }\end{array}$ & $\begin{array}{l}\text { Cultural Tourism } \\
\text { Education tourism } \\
\text { Culinary tour } \\
\text { Tracking and bamboo rafting }\end{array}$ & $\begin{array}{l}\text { telecommunications } \\
\text { network including } \\
\text { internet, Sign board, } \\
\text { tour guide, gift shop }\end{array}$ \\
\hline $\begin{array}{l}\text { Riam Anai } \\
\text { (Lok Lahung Village, } \\
42 \text { km from } \\
\text { Kandangan) }\end{array}$ & $\begin{array}{l}\text { A one-level waterfall } \\
\text { with views of } \\
\text { unspoiled natural } \\
\text { atmosphere of } \\
\text { Loksado }\end{array}$ & $\begin{array}{l}\text { Not well managed } \\
\text { Lack of supporting } \\
\text { facilities }\end{array}$ & $\begin{array}{l}\text { Natural Tourism } \\
\text { Special interest tours } \\
\text { include: tracking, mountain } \\
\text { bike, rock climbing, hiking, } \\
\text { and bike trail }\end{array}$ & $\begin{array}{l}\text { public toilet, } \\
\text { restaurant, and } \\
\text { rest point, signboard, } \\
\text { telecommunications } \\
\text { network including } \\
\text { internet }\end{array}$ \\
\hline $\begin{array}{l}\text { Haratai Waterfall } \\
\text { (Haratai Village, } 45 \\
\text { km from } \\
\text { Kandangan) }\end{array}$ & $\begin{array}{l}\text { A three-level } \\
\text { waterfall with views } \\
\text { of natural tropical } \\
\text { forests with diverse } \\
\text { flora and fauna typical } \\
\text { of Kalimantan }\end{array}$ & $\begin{array}{l}\text { Not well managed } \\
\text { Lack of supporting } \\
\text { facilities }\end{array}$ & $\begin{array}{l}\text { Natural Tourism } \\
\text { Special interest tours } \\
\text { include: tracking, mountain } \\
\text { bike, rock climbing, hiking, } \\
\text { and bike trail }\end{array}$ & $\begin{array}{l}\text { public toilet, } \\
\text { restaurant, and } \\
\text { rest point, signboard, } \\
\text { telecommunications } \\
\text { network including } \\
\text { internet } \\
\end{array}$ \\
\hline $\begin{array}{l}\text { Tinggiran Hayam } \\
\text { Waterfall } \\
\text { (Kamawakan } \\
\text { Village, } 51 \mathrm{~km} \text { from } \\
\text { Kandangan) }\end{array}$ & $\begin{array}{l}\text { A three-level waterfall } \\
\text { with views of natural } \\
\text { tropical forests with } \\
\text { diverse flora and } \\
\text { fauna typical of } \\
\text { Kalimantan }\end{array}$ & $\begin{array}{l}\text { Not well managed } \\
\text { Lack of supporting } \\
\text { facilities }\end{array}$ & $\begin{array}{l}\text { Natural Tourism } \\
\text { Special interest tours } \\
\text { include: tracking, mountain } \\
\text { bike, rock climbing, hiking, } \\
\text { and bike trail }\end{array}$ & $\begin{array}{l}\text { public toilet, } \\
\text { restaurant, and } \\
\text { rest point, signboard, } \\
\text { telecommunications } \\
\text { network including } \\
\text { internet }\end{array}$ \\
\hline $\begin{array}{l}\text { Uring Waterfall } \\
\text { (Kamawakan } \\
\text { Village, } 53 \mathrm{~km} \text { from } \\
\text { Kandangan) }\end{array}$ & $\begin{array}{l}\text { A three-level waterfall } \\
\text { with unspoiled } \\
\text { natural beauty }\end{array}$ & $\begin{array}{l}\text { Not well managed } \\
\text { Lack of supporting } \\
\text { facilities }\end{array}$ & $\begin{array}{l}\text { Natural Tourism } \\
\text { Special interest tours } \\
\text { include: tracking, mountain } \\
\text { bike, rock climbing, hiking, } \\
\text { and bike trail }\end{array}$ & $\begin{array}{l}\text { public toilet, } \\
\text { restaurant, and } \\
\text { rest point, signboard, } \\
\text { telecommunications } \\
\text { network including } \\
\text { internet }\end{array}$ \\
\hline
\end{tabular}

\section{CONCLUSION}

Loksado is rich in term of natural and cultural tourisms. The main attraction of Loksado is the views of natural tropical forest with diverse flora and fauna typical of Kalimantan. If managed properly, it becomes the potential resources to generated tourism generally in Hulu Sungai Selatan. Several weaknesses are found in Loksado tourism area, including poor management of tourism facility, quality of travel corridor movement, bad attraction management, 
some problems in transportation (i.e., road, signboard, and accessibility), and telecommunication network. The aspect related to the accessibility includes roads itself, trails, and bridges with the main threats from the slippery clay path and the landslide of slopes. Community-based tourism appears to be important to promote, with the particular objectives is increasing the local benefit to increase community participation in tourism attraction and infrastructure management. It is also possible to increase local community in accommodation services.

\section{REFERENCES}

[1] Inskeep, E. 1991. Tourism planning: an integrated and sustainable development approach. Van Nostrand Reinhold. New York.

[2] Khadaroo, J. and B. Seetanah. 2007. Transport infrastructure and tourism development. Annals of Tourism Research 34(4), 1021-1032.

[3] Adebayo, K.A. and C.O.A. Iweka. 2014. Optimizing the sustainability of tourism infrastructure in Nigeria through design for deconstruction framework. American Journal of Tourism Management 3(1), 1319.

[4] Jovanović, S., Ilić, I. 2016. Infrastructure as important determinant of tourism development in the countries of Southeast Europe. Ecoforum 5(1), 288-294.

[5] Swarbrooke, J. 1999. Sustainable tourism management. CABI Publishing.

[6] Hakim, L., M. Soemarno and S.K. Hong 2012. Challenges for conserving biodiversity and developing sustainable island tourism in North Sulawesi Province, Indonesia. Journal of Ecology and Environment 35(2), 61-71.

[7] Gunn, C. A. 1980. Tourism planning. Crane Russak. New York.

[8] Bramwell, B. and B. Lane. 2000. Collaboration and partnerships in tourism planning. Tourism collaboration and partnerships: Politics, practice and sustainability 2, 1-19.

[9] Normelani, E. 2016. The potentiality of tourism resources in Hulu Sungai Selatan Regency, South Kalimantan. Journal of Indonesian Tourism and Development Studies 5(1), 1-8.

[10] Government Regulation of Republic of Indonesia. 2011. No. 50 on the Main
Development of National Tourism 20102025. Ministry of Tourism. Jakarta.

[11] Center of Statistic Hulu Sugai Selatan Regency. 2012. Hulu Sungai Selatan in numbers 2012. Hulu Sungai Selatan Regency. South Kalimantan.

[12] United Nations of World Tourism Organization. 2012. Destination wetlands: supporting sustainable tourism. Secretariat of the Ramsar Convention on Wetlands, Gland, Switzerland \& World Tourism Organization (UNWTO) Madrid. Spain.

[13] Chesworth, W. 2008. Gabion in encyclopedia of soil science. Springer. Netherland.

[14] Normaniza, O. and S.S. Barakbah. 2006. Parameter to predict slope-soil water and root profiles. Ecological Engineering 28(1), 90-95.

[15] Mackinnon, K. 1996. The Ecology of Kalimantan Vol. 3. Periplus Editions.

[16] Hulu Sungai Selatan Department of Tourism. 2015. Accommodation in Hulu Sungai Selatan tourism area. Hulu Sungai Selatan Regency. South Kalimantan.

[17] Simmons, D.G. $1994 . \quad$ Community participation in tourism planning. Tourism Management 15(2), 98-108.

[18] Hakim, L. 2004. Dasar-dasar ekowisata. Bayumedia Press. Malang.

[19] Abdullah, S., A.A. Razak and A.A. Jaafar. 2014. Public tourism infrastructure: challenges in the development and maintenance activities. SHS Web of Conferences 12(01096), 1-8. 